\title{
Indian Tourism Industry and COVID-19: Present Scenario
}

\author{
Vineet Kumar \\ PhD Research Scholar, Punjabi University Patiala, India \\ vinitsharma678@gmail.com
}

Article History

Received 25 March 2020

Accepted 17 April 2020

Keywords

COVID-19, Indian

tourism \& Corona,

Corona impact on

tourism
Corresponding Editor

Ramesh Raj Kunwar

kunwar.dr@gmail.com

\section{Abstract}

Tourism is a backbone of economy for many countries of the world. Tourism is a big source and always helpful in generating revenue and a mean of foreign exchange. Scenario in our country is not much different and Tourism contributes to GDP of this country in a big proportion. However it's a deep matter of concern for all the stakeholders associated with tourism industry that tourism is the most affected sector in the world due to corona virus disease (COVID-19) in the beginning of 2020.COVID-19 is spreading rapidly at an unprecedented scale across continents and has emerged as the single biggest life threatening health risk in the world has faced in modern times. This paper focuses on the COVID-19 issue in India and its impact on the tourism and hotel industry, the paper has some significance, as the tourism and hotel industry greatly affected by the COVID-19 crisis worldwide. India is the 7th largest country of the world and rich with various tourism resources and millions of tourists arrive annually, which contributes to the country's GDP.The need of the hour, is to take early steps to overcome the present slowdown in tourism industry by analyzing its long term impacts at the earliest. 


\section{Introduction}

Corona virus disease (COVID-19) threat originated from central China's Hubei province in Wuhan city in the month of December 2019 and continues to adversely affect more than 150 countries and claimed more than 50,000 lives globally In a matter of weeks, over 100,000 of cases and thousands of deaths were confirmed globally, On January 30, 2020, the World Health Organization (WHO, 2020) designated the COVID-2019 outbreak a "public health emergency of international concern." Scientists rapidly started working to elucidate the characteristics of the virus, including transmissibility, death rate, and origin( perlman,2020).Government started working to handle the situation by imposing lockdown, taking appropriate actions and by communicating precautionary information regarding COVID-19, developed economies of the world, medically advance countries could not deprived themselves from COVID-19.Europe has also become the epicenter of COVID-19. Italy is the worst hit country after China. India is also going through the phase of complete lockdown consequently Indian tourism Industry facing a big challenge.

\section{Indian tourism industry}

India is the birthplace of the four religions of the world namely Hinduism, Buddhism, Jainism and Sikhism. India having total 38 world heritage sites. India attracts tourist from all over the world. India's foreign tourist arrival is also increasing. (Ministry of Tourism-2019) In India 2017, 10.04 million foreign tourists arrived and in 2018, 10.56 million tourists arrived with $5.2 \%$ increase.(IBEF-2019) Total contribution by travel and tourism sector to India's GDP is expected to increase from Rs $15,24,000$ crore (US\$ 234.03 billion) in 2017 to Rs 32, 05,000 crore (US\$ 492.21 billion) in 2028. Total earning from the sector in India stood at US\$28.6 billion in 2018 and is targeted to reach US\$ 50 billion by 2022. .(Ministry of Tourism-2019) number of foreign tourist arrivals for medical purpose is also increasing. Data and fact provided in these studies clearly shows that India is ready to carry forward Indian tourism industry to the next level, which will accelerate the Indian tourism industry. Digital transformation in tourism industry, advancement in technology, better accessibility like E-VISA, Visa on arrival, hassle free VISA formalities, expressed check-in, are the most advanced concept emerged in this decade. Now the world tallest statue is also found in India, known as statue of liberty, inaugurated in 2018 and has emerged as the most favorite tourist spots of India. Indian tourism industry having diverse accommodation sector to accommodate the need of travelers including national and international luxurious hotel chains to home stay schemes and known for its hospitality worldwide. Meditation, yoga, adventure tourism are also one of the emerging trends under tourism industry as Indian Vedas contains many philosophies for yoga and meditation and foreigners across the world find India as suitable destination for yoga and meditation. India's north, east, west and south parts 
known for its diversity in terms of climatic conditions, flora \& fauna, cultural values and lifestyles. At the end of 2019 India tourism industry was confidently continuing with its fast growth pace without any concern about any kind of threat to Indian tourism industry but now situation has been changed due to COVID-19 crisis in India and globally.

\section{Entry of COVID-19 in India}

In the beginning of 2020 Indian tourism industry was all set to accelerate its pace towards development. India was unaware about the impact of biological disaster called Corona virus disease (COVID-19) threat originated from central China's Hubei province in Wuhan city in the month of December 2019 and continues to adversely affect more than 150 countries and claimed more than 50,000 lives globally so far.(WHO INDIA-2020) In the context of India on $30^{\text {th }}$ January 2020, a laboratory confirmed case of COVID-19 was reported in Kerala. Kerala state is one of the favorable state among foreigner tourist, which is also known as 'God's own country'. Since Januarary 2020 COVID-19 has spread in almost all the states \& Union territory of India and claimed more than 20 lives and approx 1000 confirmed cases of COVID19 so far. On $24^{\text {th }}$ March 2020 Prime Minister of India announced 21 days lockdown and banned all domestic and international arrival and departure through all means of transportations. Hotel Industry will also not entertain any kind of new booking and check-in in the hotels. This lockdown to handle COVID-19 affected all segments of Indian tourism industry adversely. Tourism product is a perishable product which cannot be stored and sold later, this feature of tourism product push tourism industry in to heavy loss in terms of poor revenue generation. This is one of the worst crises ever to hit the Indian tourism industry. As the news of the virus start picking up from November, the percentage of cancellation started going up in this segment exponentially and is reaching peak of almost $80 \%$ now in March in many Indian locations. The value of risk from this segment will be in multiples of tens of thousands of crore. WTTC(2020) "WTTC figures show the stark impact on the Travel $\&$ Tourism sector of the present COVID-19 outbreak with analysis now suggesting that up to 50 million jobs are at risk in the sector globally". Tourism industry is in threat globally and will also affect employment adversely. Indian tourism industry is source of employment, livelihood for many people who are directly and indirectly linked to tourism industry. Without government intervention it will be difficult to overcome this situation where tourism industry is at the worst phase in $21^{\text {st }}$ century.

\section{Impact on Indian hospitality industry}

Indian hospitality industry is one of the largest tourism Industry of the world and more than 2000 hotels and 1000 restaurants enlisted under FHRAI(2020) Federation of hotel restaurant association of India),which provide employment to lakhs of 
people. Due to lockdown in India and COVID-19 threat, process of reservation cancellation is being carried out which will adversely affect the hotel business and likely to face revenue loss in 2020 and the parallel negative impact can be seen on employment in the future as a cost cutting tool. There are few recent response by the hotels business group on COVID-19.(Tourism Breaking News-2020) Sarovar anticipates $12-15 \%$ decline in revenue per available room for 2020.Intercontinental hotels group anticipates global revPAR decline of around $60 \%$.As per HVS hotels should maintain pricing charts through the crisis. This is quite understandable that during and after this crisis hotel industry will loss the revenue, as per the HVS report hotels should maintain pricing charts through the crisis as once the prices of rooms reduced it becomes difficult to lift up later, however by keeping in mind the present scenario it cannot be assessed that how long this crisis will last for. (UNWTO-2020) International tourism to plunge up to $30 \%$ due to virus. The drop in arrivals will lead to an estimated loss of $\$ 300-450$ billion in international tourism receipts, almost one third of the $\$ 1.5$ trillion generated in 2019, Tourism is among the hardest hit of all economic sectors, due to COVID-19 threat foreign tourist arrival will be declined as foreign tourist arrival is the most favorable source for foreign exchange earnings, simultaneously revenue generated by hospitality industry will be affected adversely. Europe is known as the top most zone in terms of generating revenue from tourism and top foreign tourist arrival countries found in Europe i.e. Italy, France and Spain are among the hardest hit countries due to COVID-19 crisis, this impact on European tourism industry can also be seen in the Indian hospitality industry in the coming future as a large number of travelers visit India from Europe. Indian hospitality industry is in the developing stage, so Indian stakeholders need to take early step to handle the situation.

\section{Impact on travel and airline business}

Travel agencies and tour operators can also face financial crunch in near future as tourist's frequency to visit India will be declined. All segment of tourism inbound, outbound, domestic, MICE will be affected. The way hotel bookings are being canceled, in the same way packages sold by travel agencies and tour operators for inbound, outbound, domestic segments are also being canceled. MICE segment is one of the important segment as per revenue generation for a travel agencies but due to present crisis all kind of events, meeting, conferences have been canceled or postponed.(Business Today-2020) MakeMyTrip's founders to draw zero salary; top brass to take $50 \%$ cut. Travel agents will be forced to take such action due to financial crunch in the near future which is not good for travel business. Travel agents also earn revenue from airline ticketing but for the purpose of safety precautions any kind of domestic international travel is banned as per advisory issued by Government of India during lockdown period. Airlines are also worst hit from this crisis and might 
lead to financial crunch to airlines industry. (IATA-2020) airlines revenues in 2020 to decline by $44 \%$ compared to 2019 . Which means half of the revenue will be declined in aviation sector by 2020 , which will be the greatest setback for the aviation sector globally. This can put airlines jobs at risk in the near future. In India the passenger's traffics at all the international airports have been banned till lockdown time and passenger's traffic will be reduced in the near future due to COVID-19 crisis. In the present times travel and airline business staff is being sent on leave with no pay, which is not good for the industry and will create unemployment in travel and airline business. This crisis is creating unbalance in the economy. It would not be wrong to say that economy will move towards recession, if early step will not be taken by government and all its stakeholders, which will impact the GDP rate of the country adversely and for India being a developing economy it would be a challenge at tackle in the near future.

\section{Suggestions to overcome the impact}

Indian tourism industry is the most affected industry influenced by the contagious COVID-19, the contagious virus has reached cities and towns all over the country within a few days and adversely hit the tourism industry, and consequently hotels and tour operators are temporarily closed or reduced their room inventory and operation. This impact can be reduced by using certain immediate measures, short term measures and long term plans. The government and stakeholders should offer financial aid to tourism industry. Tourism enterprises should react quickly to the situation; adjust both long-term and short-term strategies, in aspects such as cost control and employee arrangement. It is important for tourism enterprises to stay competitive when the market is unstable, and should maintain prices chart throughout the crisis.

Tourism enterprises can take the certain measures to maintain their cash flow in the near future by suspending unnecessary or least important operational material purchases, by delaying outsourcing payments and by encouraging employees to take annual leaves and unpaid leaves, moreover tourism industry stakeholders can maintain business by other ways like adjusting their market mix and distribution channels. Present lockdown time period can also be utilized by conducting online training and development programs for the employees, which will help to enhance hospitality skills or can, upgrade their expertise in the diverse field of Tourism industry to adapt well in the contemporary digital environment.

\section{Conclusion}

Severe impacts from COVID-19 can be reducing hotels booking, airlines booking, cancelations of events, reduction of staff as a cost cutting measures and risk to airlines, hotels, travel agencies jobs in the near future as the revenue generated 
by tourism industry will be reduced. Half of the revenue can be declined in 2020 as compare to the previous year, however, despite severe cuts in business and predictions that normal travel patterns would take years to return. To handle this situation and for the upliftment of tourism industry government should come forward, without government intervention it would be difficult to overcome the present situation and financial crunch. Government must give certain relaxation on taxes imposed on tourism industry, or to provide certain soft loans with minimum interest rates and must issue additional funds for the betterment of tourism industry in the near future.

One thing made very clear by this crisis is the fragile nature of tourism business, and therefore the need to have contingencies for even unpredictable events as this crisis has shaken the entire tourism industry globally.

\section{References}

Business Today (2020). COVID-19 impacts. Retrieved from https://www. businesstoday.in/current/economy-politics/coronavirus--impact-makemytripsfounders-to-draw-zero-salary-top-brass-to-take-50-cut/story/399281.html

India Brand Equity Foundation. (2019). Indian tourism and hospitality industry analysis. Retrieved from https://www.ibef.org/industry/indian-tourism-andhospitality-industry-analysis-presentation

Ministry of Tourism, India (2019). Tourism statistics. Retrieved from http://tourism. gov.in/sites/default/files/Other/India\%20Tourism\%20Statistics\%20at\%20a\%20 Glance\%202019.pdf

Ministry of Tourism, India (2019). Development of medical tourism. Retrieved from http://tourism.gov.in/sites/default/files/usq\%20449\%20for\%2025062019.pdf

Perlman, S. (2020). Another decade, another coronavirus. The New England Journal of Medicine, 382, 760 -762. http://dx.doi.org/10.1056/ NEJMe2001126

Tourism Breaking News. (2020). COVID-19 impact on industry. Retrieved from https://tourismbreakingnews.com/tag/federation-of-associations-in-indiantourism-and-hospitality/

Tourism Breaking News (2020). COVID-19 impact on industry. Retrieved from https://tourismbreakingnews.com/category/hotels/

Tourism Breaking News (2020) COVID-19 impact on industry. Retrieved from https://tourismbreakingnews.com/category/aviation/

The Economic Times (2020). Retrieved from https://m.economictimes.com/news/ international/business/international-tourism-to-plunge-up-to-30-due-to-virusunwto/articleshow/74849024.cms 
World Health Organization, India (2020). Novel Corona virus Situation Report-1. Retrirved frm https://www.who.int/docs/default-source/wrindia/india-situationreport-1.pdf?sfvrsn=5ca2a672_0

World Health Organization (2020). Statement on the second meeting of the International Health Regulations (2005) Emergency Committee regarding the outbreak of novel coronavirus (2019-nCoV). Retrieved from https://www.who. $\mathrm{int} /$ news-room/detail/30-01-2020-statement-on-thesecond-meeting-of-theinternational-health-regulations-(2005)- emergency-committee-regarding-theoutbreak-of-novel-coronavirus-(2019-ncov)

World Travel and Tourism Council (2020). COVID-19 impact. Retrieved from https://www.wttc.org/about/media-centre/press-releases/press-releases/2020/ coronavirus-puts-up-to-50-million-travel-and-tourism-jobs-at-risk-says-wttc/ 